Patrizia Moselli

The Challenge is "Now" and «In the Future" for Bioenergetic Analysis

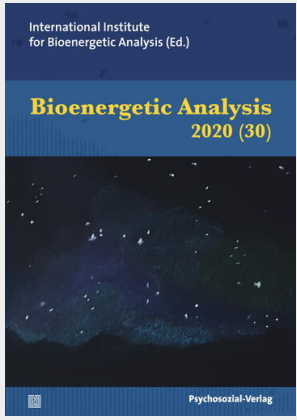

Bioenergetic Analysis

30. Volume, No. 1, 2020, Page 75-85

Psychosozial-Verlag

DOI: 10.30820/0743-4804-2020-30-75 
Reviewers for this issue:

Garry Cockburn, Léia Cardenuto and Maê Nascimento

Translators of abstracts for this issue:

Claudia Ucros (French), Pablo Telezon (Spanish), Maria Rosaria Filoni (Italian), Maê Nascimento and Edna Veloso de Luna (Portuguese), Thomas Heinrich (German), Olga Nazarova and Alesya Kudinova (Russian)

Submissions for consideration for the next volume of Bioenergetic Analysis must be sent to Leia Cardenuto (leiacardenuto52@gmail.com) between June $1^{\text {st }}$ and September $1^{\text {st }}$, 2020.

Bibliographic information of Die Deutsche Nationalbibliothek (The German Library) The Deutsche Nationalbibliothek lists this publication in the Deutsche Nationalbibliografie; detailed bibliographic data are available at http://dnb.d-nb.de.

2020 Psychosozial-Verlag, Gießen, Germany

info@psychosozial-verlag.de

www.psychosozial-verlag.de

\section{(c) $(1) \Theta \Theta$}

This work is licensed under the Creative Commons Attribution-NonCommercialNoDerivatives 4.0 International License (CC BY-NC-ND 4.0). This license allows private use and unmodified distribution, but prohibits editing and commercial use (further information can be found at: https://creativecommons.org/licenses/by-nc-nd/4.0/). The terms of the Creative Commons licence only apply to the original material. The reuse of material from other sources (marked with a reference) such as charts, illustrations, photos and text extracts may require further permission for use from the respective copyrights holder.

Cover image: Vincentia Schroeter, Starry Night (C) Vincentia Schroeter Cover design \& layout based on drafts by Hanspeter Ludwig, Wetzlar Typesetting: metiTec-Software, me-ti GmbH, Berlin, www.me-ti.de

https://doi.org/10.30820/0743-4804-2020-30

ISBN (PDF-E-Book) 978-3-8379-7679-3

ISBN (Print) 978-3-8379-8295-4

ISSN (Online) 2747-8882 · ISSN (Print) 0743-4804 


\section{The Challenge is "Now" and "In the Future" for Bioenergetic Analysis ${ }^{1}$}

\section{Patrizia Moselli}

\section{Abstracts}

Alexander Lowen developed his theory by observing what happened in the evolution of the child and in the construction of his/her defenses. Character defenses block vitality and therefore we could define "vitality" as the procedural memory of our "natural child" who, in the course of their development, has created so many characterological adaptations. Vitality is blocked because it is disorganized by developmental traumas that prevent the natural process of adaptation generated by a loss of love and by attachment disorders. So, working with the life force becomes the center of the therapeutic process, since our vitality is blocked by disorganized defenses that we could consider to be real post-traumatic stress syndromes. Rebuilding "safe relationships" becomes fundamental to create that energy field in which the individual can experience his/her "asleep" vitality. The therapist must be able to convey bonds of attachment that can connect the patient to both humanity and to nature. The therapeutic relationship explores the nature of these bonds, which is fundamentally sensory and emotional, intrinsically "intelligent", as guided by profound regulatory processes.

Key words: character, complexity, defense, energy, planetary humanism

\section{Le défi du "Maintenant" et du "Dans le futur" pour l'Analyse Bioénergétique (French)}

Alexander Lowen a développé sa théorie en observant ce qui se passait dans l'évolution de l'enfant et dans la construction de ses défenses. Les défenses de caractère bloquent la vitalité et nous pourrions donc définir la "vitalitê" comme la mémoire procédurale de notre "enfant naturel", celui qui, au cours de l'évolution, a créé de nombreuses adaptations caractérologiques. La vitalité est bloquée parce qu’elle est désorganisée par des traumatismes du développement qui empêchent le processus naturel d’adaptation généré par une perte d'amour et par des troubles de l'attachement. Ainsi, travailler avec la force vitale devient le centre du processus thérapeutique, puisque notre vitalité est bloquée par des défenses désorganisées que nous pourrions considérer comme de

1 Panellist Response to Guy Tonella's Keynote Address to the $25^{\text {th }}$ IIBA Conference in Portugal, 25 May 2019. 
véritables syndromes de stress post-traumatique. Reconstruire de la "sécurité dans la relation" devient fondamental pour créer ce champ d'énergie qui permet à l'individu de faire l'expérience de sa vitalité “endormie". Le thérapeute doit être capable de transmettre des liens d'attachement qui puissent connecter le patient à la fois à l'humanité et à la nature. La relation explore la nature de ces liens, qui sont fondamentalement sensoriels et émotionnels, intrinsèquement "intelligents", guidés par de profonds processus de régulation.

\section{El desafio es "ahora" y "en el futuro" para el analisis Bioenergetico (Spanish)}

Alexander Lowen desarrolló su teoría al observar lo que sucedió en la evolución del niño y en la construcción de sus defensas. Las defensas del carácter bloquean la vitalidad y, por lo tanto, podríamos definir la "vitalidad" como la memoria procesal de nuestro "niño natural" que, en el curso de la evolución, ha creado tantas adaptaciones caracterológicas. La vitalidad está bloqueada porque está desorganizada por traumas del desarrollo que impiden el proceso natural de adaptación generado por una pérdida de amor y por trastornos del apego. Entonces, trabajar con la fuerza vital se convierte en el centro del proceso terapéutico, ya que nuestra vitalidad está bloqueada por defensas desorganizadas que podríamos considerar síndromes de estrés postraumáticos reales. La reconstrucción de "relaciones seguras" se convierte en fundamental para crear ese campo de energía en el que el individuo puede experimentar su vitalidad "dormida". El terapeuta debe ser capaz de transmitir vínculos de apego que puedan conectar al paciente con la humanidad y la naturaleza. La relación explora la naturaleza de estos vínculos, que son fundamentalmente sensoriales y emocionales, intrínsecamente "inteligentes", guiados por procesos reguladores profundos.

\section{La sfida è "ora" e "nel futuro" per l'analisi bioenergetica (Italian)}

Alexander Lowen ha sviluppato la sua teoria osservando cosa accade nella fase evolutiva del bambino e nella costruzione delle sue difese. Le difese caratteriali bloccano la vitalità e quindi potremmo definire la "vitalità" come la memoria procedurale del nostro "bambino naturale" che, nel corso della fase evolutiva, ha creato così tanti adattamenti caratteriali. La vitalità è bloccata perché disorganizzata da traumi dello sviluppo che impediscono il naturale processo di adattamento generato dalla perdita dell'amore e dai disturbi dell'attaccamento. Quindi, lavorare con la forza vitale diventa il centro del processo terapeutico, poiché la nostra vitalità è bloccata da difese disorganizzate che potremmo considerare vere sindromi da stress post-traumatico. Ricostruire "relazioni sicure" diventa fondamentale per creare quel campo di energia in cui l'individuo può sperimentare la sua vitalità "addormentata". Il terapeuta deve essere in grado di trasmettere legami di attaccamento che possono collegare il paziente sia all'umanità che alla natura. La relazione esplora la natura di questi legami, che sono fondamentalmente sensoriali ed emotivi, intrinsecamente "intelligenti", guidati da profondi processi regolatori. 


\section{Para a Análise Bioenergética, o Desafio é "Agora" e "No Futuro" (Portuguese)}

Alexander Lowen desenvolveu sua teoria observando o que acontecia na evolução da criança e na construção de suas defesas. As defesas de caráter bloqueiam a vitalidade e, portanto, poderíamos definir "vitalidade" como a memória de procedimento de nossa "criança natural" que, durante a evolução, criou tantas adaptações caracterológicas. A vitalidade é bloqueada porque é desorganizada por traumas de desenvolvimento que impedem o processo natural de adaptação gerado por uma perda de amor e por distúrbios de apego. Portanto, trabalhar com a força vital torna-se o centro do processo terapêutico, pois nossa vitalidade é bloqueada por defesas desorganizadas que poderíamos considerar verdadeiras síndromes de estresse pós-traumático. Reconstruir "relacionamentos seguros" torna-se fundamental para criar o campo de energia em que o indivíduo pode experienciar sua vitalidade "adormecida”. O terapeuta precisa ser capaz de transmitir laços de apego que possam conectar o cliente à humanidade e à natureza. O relacionamento explora a natureza desses vínculos, que é fundamentalmente sensorial e emocional, intrinsecamente “inteligente", porque é guiada por processos regulatórios profundos.

\section{Die Herausforderung ist "Jetzt" und "in der Zukunft" für die Bioenergetische Analyse (German)}

Alexander Lowen entwickelte seine Theorie bei der Beobachtung dessen, was in der Evolution des Kindes und in der Konstruktion seiner Widerstände geschieht. Charakterliche Abwehr blockiert die Lebendigkeit und damit können wir "Lebendigkeit" definieren als das prozedurale Gedächtnis unseres “natürlichen Kindes”, das im Laufe der Evolution so viele charakterologische Adaptierungen geschaffen hat. Lebendigkeit ist blockiert, da sie desorganisiert wurde durch Entwicklungstraumata, die den natürlichen Prozess der Adaption verhindern durch den Verlust von Liebe und Bindungsstörungen. So wird das Arbeiten mit der Lebenskraft zum Zentrum des therapeutischen Prozesses, da unsere Lebendigkeit blockiert ist durch desorganisierte Abwehr, die wir als real post-traumatische Stresssyndrome ansehen können. Der Wiederaufbau "sicherer Beziehungen" wird grundlegend, um das Energiefeld zu bilden, in dem das Individuum seine "schlafende" Lebendigkeit erfahren kann. Die Therapeut_in muss fähig sein, bonds of attachment zu fördern, die die Patient_in sowohl mit der Menschlichkeit als auch mit der Natur verbinden kann. Die Beziehung entdeckt die Natur dieser Bänder, was fundamental sensorisch und emotional, intrinsisch "intelligent" sowie durch einen profunden regulatorischen Prozess geleitet ist.

\section{Вызов Биоэнергетическому Анализу в "сегодняшнем дне" и "в будущем" (Патриция Мозелли) (Russian)}

Александр Лоуэн разработал свою теорию наблюдая за тем, что происходило в процессе развития ребенка и построении его защит. Защиты 
характера блокируют жизнеспособность, а следовательно “жизнеспособность” можно определить как процедурную память нашего “естественного ребенка”, который в процессе своего развития создал так много характерологических адаптаций. Жизнеспособность заблокирована, потому что она была дезорганизована травмами развития, которые препятствуют естественному процессу адаптации, вызванному утратой любви и нарушениями привязанности. Восстановление "безопасных отношений” становится необходимым для создания энергетического поля, в котором человек сможет ощутить свою “спящую” жизнеспособность. Таким образом, работа с жизненной силой оказывается в центре терапевтического процесса, поскольку наша жизнеспособность заблокирована дезорганизующими защитами, которые можно считать реальными посттравматическими стрессовыми синдромами. Терапевт должен быть способен передать узы привязанности, которые могут соединить пациента как с человечеством, так и с природой. В отношениях исследуется природа этих уз, которые являются сенсорными и эмоциональными в своей основе, “разумными” по своей сути, поскольку ими управляют сильнейшие регуляторные процессы.

\section{Introduction}

This article represents my comments on Guy's Tonella interesting speech the $25^{\text {th }}$ IIBA Conference. Guy's presentation raises interesting questions for bioenergetic analysts, asking us to consider and respond to the needs and challenges of the "Global Village". This brings to mind the reflections of Edgar Morin (1990), in his essay On Complexity, and more specifically what he defines as "planetary humanism".

I make this comparison because, at the same time that I received Guy's speech, I also invited Edgar Morin to Italy (such a curious case of "synchronicity") for the annual conference of the Italian Society for Psychotherapy, where every approach is represented. As Guy reminds us, as bioenergetic analysts, we have to consider globality as it represents a challenge to complexity.

\section{Complexity and Simplicity}

We should also be open to a new kind of knowledge that overcomes the separation between the different kinds of knowledge. In today's world we can educate ourselves to understand a more complex knowledge. Guy reminds us that we must not cultivate/follow the aims of simple thinking which might lead us to control and dominate the true reality. Rather, as bioenergetic analysts we need to practice 
a more complex form of thinking that can work with reality and dialogue and negotiate with it.

At this point, let's dispel some illusions, the first of which is believing that complexity can lead to the elimination of simplicity. In effect, according to Morin's opinion, theory is a complex, anthropological-biological-physical whole. Human beings cannot be separated from nature: they originate within living physical nature. At the same time, they emerge from nature through culture and knowledge. Therefore, what is human is also complex because it is multifaceted. Humanity is not just animality, and yet there is no humanity without animality. So, these reflections seem to me to fully affirm the thoughts and visions of both Alexander Lowen and Wilhelm Reich.

In today's world, as Guy explains, the cosmic condition of every individual is situated within an enormous expansion in the Cosmos, formed by billions of galaxies and stars, of which the Earth is just a small part. Therefore, order and disorder coexist, as well as animality and nature, all of which form Man's condition. Man is linked both to his biophysical origin and to the psycho-socio-cultural one, and these are in relationship with each other.

Guy started talking about the Big Bang. I like to think about the rhythms and sounds of the fetus in the womb of the mother as humanity's "Big Bang". As Lowen reminds us, we were born of the Cosmos (Lowen, 1984), born by nature and life, but because of our culture and mind, we have become strangers to this universe. According to Morin's assumptions, and as Guy points out, in terms of evolution, we bioenergetic analysts need to evolve our thinking (theories), allowing us to acquire new knowledge and going beyond the physical separation typical of the $19^{\text {th }}$ and $20^{\text {th }}$ century paradigms.

\section{The Challenge for Bioenergetic Analysis}

We need a bioenergetic theory that encapsulates and educates our field based on this complexity. For example, the basic problem of how to make the "old" coexist with the "new" reflects the evolution of bioenergetic analysis. Morin states that culture is not only fragmented in separate parts but also split in two blocks. This seems to reflect also the nature of our bodies and thought. Thus, on the one hand we have humanistic culture, which represents the world of our emotions, and on the other the scientific one, which represents the building of our cognition (Morin, 1990).

I guess that this is the challenge bioenergetic analysis will be involved with, "now" and "in the future". For instance, respecting our humanistic roots and placing love as an important therapeutic agent. But we also need to pay attention to rigorous research that allows us to dialogue with and be listened to by the scientific community. This can allow us to not be confused and diffused as 
in so many "New-Age" approaches (where even Wikipedia unfortunately places us).

When teaching, I have shown two videos about pleasure and pain in childhood: they are taken from two Infant Research protocols granted by "La Sapienza" University in Rome ${ }^{2}$. I generally use them in conferences when I compare Bioenergetic Analysis with other approaches, to show the role of implicit memory, assuming that this kind of memory will remain embodied. The videos illustrate that the "fundamental processes that regulate non-verbal interaction remain the same throughout life" (Beebe \& Lachmann, 2002).

As Reich stated, if relationships related to pleasure, attunement and love develop the sense and sensations of pleasure in the child's body, then relationships related to sadism, repression, and neglect must create in the child's body sensations of resistance, pain and negativity which are inscribed in the bones, cells and in the immune system (Reich, 1933).

Pain is inscribed in the muscular structure at a molecular level. Epigenetics explains how inflammations and contractions also affect the role of health because these implicit memories remain inscribed in the adult's body, imprisoning life's energy. Thus "the old" theory returns, because in the "old days" we were experts in dealing with resistance and negativity.

The challenge for therapists, especially in this narcissistic world which avoids conflict, is how to deal with our client's negativity without scaring them. As we all know, our life force is often restrained and encapsulated in resistances. At the same time, we know that successful therapeutic depth needs an energetic and dynamic model. Without a model of a deeper primary process at work, psychotherapy is restricted to compensation, adaptation, a cognitive understanding of compromise, and of reluctant acceptance.

\section{The Work of Bennett Shapiro}

So, the fundamental questions seem to be: how can the life force be restored in the world of today?; how can we mobilize the still stagnant, contracted and blocked energy?; how can we restore life pulsations in the body and concretely work with this energy in the therapeutic field?

Guy has already answered these questions in depth. I have also found the contributions of our IIBA Faculty Emeritus colleague, Bennett Shapiro, very interesting. Bennett has given us so many reflections and techniques about dealing with resistance. He can also be considered an expert in the use of humour and play in psychotherapy. His work with the subselves, in my opinion, allows us to

2 Material is kindly provided by Dr Renata Tambelli, PhD, Department of Dynamic and Clinical Psychology, "La Sapienza” University in Rome. 
differentiate between the Ego states, and helps us integrate them with object relational theories.

Shapiro starts with the exploration of devils and negativity, then develops a subselves theory that, in my view, makes him very current in the modern psychotherapy panorama and allows us to be aligned and dialogue with many trauma theories, e. g. Ogden \& Fisher (2105). Shapiro (2009) states that

"Subselves are islands of shock, fear, pain, anger, formed in childhood. They protect us from being threatened again and they have a lot of energy."

This is a concept close to the internal psychic object. The concept of internal psychic objects is the result of the internalization of parental figures and which are erected in the Ego, reinforcing the task of removal. The Ego partially assumes the task of representing the object in internal psychic life, so as to be able to maintain the relationship. This starts a structural differentiation in the Ego, in consideration of the fact that what was once an external object relationship now comes to be internally represented by a relationship between a part of the Ego that still remains, and another part that now represents the object. The focus of the work is to energize what is present even if not yet perceived or thought. Every subself has its own body and psychological characteristics, the intuition being that each of them can be expressed in a bioenergetic way.

Bennett developed an original modality to get in touch with resistances and he developed techniques intended to build a system of greater energy charge in the client. All this work is done to avoid scaring the patient, whilst allowing the therapist to dialogue with the patient's resistances. The patient will then be able to sustain a greater energy charge and therefore increase/improve their vital force (Shapiro, 2008).

\section{Another Challenge}

In fact, in our age of complexity, another challenge is represented by the aspect of play and lightness. If we think of the social media, for instance, people seem to avoid everything that is tragic, painful; and complicated. Unfortunately, life is also tragic, painful and complicated but the narcissistic culture seems sometimes to take us away from these visions/aspects of life.

At the beginning, the therapist is like a "ferryman", the fascinating metaphor used by Guy, moving, from my point of view, from culture to nature. The therapist is confident in the self-regulating force, helping the client to see their fear of emotion, their fear of instinctual forces, and helping them to build the vital trust to maintain their identity in reality. However, our clients are sometimes unable 
to face the challenges of reality. In this sense, I like to think about the Therapon $\left(\vartheta_{\varepsilon \rho \alpha \pi \omega \nu}\right)$ metaphor. Therapon is the patient/warrior's helper, who, on the chariot, gives arrows and weapons to the patient/warrior who uses them to deal with his life battles.

So, psychotherapy can be seen as an epic voyage. The client, like the Epic Hero, goes through the "tragedy" of life. To escape, however, the patient exists in a world made by relief from pain, but also by dissociation. The warrior metaphor leads us also to reflect on how a healthy aggressiveness is fundamental for selfdetermination in our difficult and complex times. I think of the Latin word, $A d$ gredior (to approach, advance, attack, undertake, seize opportunity, attempt) that strongly connects to vitality.

In fact, it is only when we are grounded in our emotions - both positive and especially negative ones - that we truly meet our life force. This brings us back to the paradox of complexity. Therefore, therapists must have the ability to be more and more grounded in their feelings and reality and avoid taking refuge in "mythical" aspects that separates them from the client.

In Bioenergetic Analysis what is important nowadays are the following:

$>$ Going slowly

$>$ Building trust and connection

$>$ Transmitting empathic resonance

$>$ Helping clients to find their own locus of control in the body

$>$ Working on deep shame and self-hated

$>$ Dealing with the client's feelings of anger and rage emerging from the past

\section{Conclusion}

In my view, there are three categories of important challenges that Edgar Morin has brought to our attention that everyone actively involved in Bioenergetic Societies, such as Presidents, Directors, Teaching Committee members must face. These are:

$>$ Cultural challenge: on the one hand, there is humanistic knowledge and on the other, technical-scientific culture. It is fundamental for us to integrate both these dimensions in an ethical vision. This means investing much more in the next generation and in their ability to get involved in "passionate" research.

$>$ Sociological challenge: thought and emotion must be in a constant dialogue. Thinking must always be integrated into an emotional vision of the world. As Lowen reminds us, knowledge and thinking are never enough to enter the patient's world. Our thinking alone will never be enough to fully guide us as therapists. We need our feelings to enter the territory of the person who is our client. 
$>$ Civic challenge: the therapist's role must be considered in a broader context. Third millennium challenges have to do with so many problems, not only regarding private practice but also concerning the application of bioenergetic analysis to other fields that are characterized by democratic deficits: for example, social integration, the common good, the environment, working with disadvantaged classes, and so on.

\section{Personal Note}

In the history of our community I have experienced that sometimes it has not been easy to deal with conflicts that arise from differences concerning individual and theoretical visions. Personally, I believe that healthy conflict based on love and vitality should not lead to a fear of confrontation, but rather to a more authentic encounter with others. Of course, our visions may be different, but we should remember that we have all a "common base". I therefore think that all of us should make a considerable effort and pay a lot of attention, both as individuals and as members of a community, to the relational and communicative aspects of belonging to the IIBA.

This brings us back to respect for our roots and at the same time, it pushes us towards the evolution of our approach both "now" and "in the future".

\section{References}

Beebe, B. \& Lachmann, F.M. (2002). Infant research and adult treatment: Co-constructing interactions. New York: The Analytic Press/Taylor \& Francis Group.

Heinrich-Clauer, V. (Ed.). (2011). Handbook Bioenergetic Analysis. Gießen: Psychosozial-Verlag.

Lowen, A. (1984). Narcissism: Denial of the True Self. New York: Macmillan.

Lowen, A. (1995). Joy: Surrender to the Body and to Life. New York: Penguin.

Morin, E. (1990). Introduction à la pensée complexe. Paris: Ed. Du Seuil.

Moselli, P. (Ed.). (2008). Il guaritore ferito: La vulnerabilità del terapeuta. Milano: FrancoAngeli.

Ogden, P. \& Fisher, J. (2015). Sensorimotor Psychotherapy. London, New York: W. W. Norton \& Co.

Reich, W. (1980). Character Analysis. New York: Farrar, Straus \& Giroux.

Shapiro, B. (2000). Will Iceberg Sink Titanic? Bioenergetic Analysis, 11(1), 33-42.

Shapiro, B. (2006). Bioenergetic Boundary Building. Bioenergetic Analysis, 16, 153-178.

Shapiro, B. (2008) in I/ guaritore ferito: La vulnerabilità del terapeuta. Ed. P. Moselli. Milano: FrancoAngeli.

Shapiro, B. (2009). Handbook for SIAB Workshop. Roma: Private circulation. 


\section{About the Author}

Patrizia Moselli is the Director of S.I.A.B. (Italian Society for Bioenergetic Analysis) and Past President F.I. A.P. (Italian Federation of Psychotherapy Associations), BOT member of SIPSIC (Italian Society for Psychotherapy), IIBA International Trainer and Faculty member, Senior Trainer IACP (Person Centered Approach Institute, Italy). She has collaborated with Carl Rogers in facilitating intercultural meeting groups in Ireland, France, Hungary. Author of the book: Il guaritore ferito (The Wounded Healer) (first edition: 1990; second edition: 2007). Author for Bioenergetic Analysis and Reichian therapy for International Dictionary of Psychotherapy edited by Salvini and Nardone (2019). Many of her essays are published in Italian and international magazines and she is the author of several scientific articles.

mail@siab-on-line.it 


\title{
Love as Regulator of the Life Force ${ }^{1}$
}

\author{
Pye Bowden
}

\section{Abstracts}

The author proposes a role for love in the regulation of the body. Regulation of the life force is critical for a newborn baby because the baby cannot regulate itself and because early patterns of regulation have surprising longevity. A mother who loves her baby is regulated by her own loving, since pleasurable emotion is the consequence of a body that is regulated. She can then pass this regulation onto the baby, body to body. Lowen surmised that love was somehow connected to the organ of the heart and McCraty et al. from the HeartMath Institute have confirmed this connection and have demonstrated that the heart is also responsible for the central system-wide signalling that synchronises the body as a whole in pleasurable feelings such as love. The author shares a personal reflection that illustrates the power of love in the life and death struggles of early infancy.

Key words: love, homeostasis, primordial feelings, heart, coherence

\section{L'amour comme régulateur de l'élan vital (French)}

L'auteur propose un rôle pour l'amour dans la régulation du corps. La régulation de la force de vie est essentielle pour un nouveau-né car le bébé ne peut pas se réguler tout seul et parce que les modèles de régulation précoces qu'il met en place ont une longévité surprenante. Une mère qui aime son bébé est régulée par son propre amour, car une émotion agréable est la conséquence d'un corps qui se régule. Elle peut ensuite transmettre cette régulation au bébé, de corps à corps. Lowen a supposé que l'amour était en quelque sorte relié à l'organe du cœur. McCraty et al. de l'Institut HeartMath ont confirmé cette connexion et ont démontré que le cœur est également responsable du signal central qui synchronise le corps dans son ensemble par le biais des sensations agréables telles que l'amour. L'auteur partage une réflexion personnelle qui illustre le pouvoir de l'amour dans les luttes de la vie et de la mort dans la petite enfance.

1 Panellist Response to Guy Tonella's Keynote Address to the $25^{\text {th }}$ IIBA Conference in Portugal, 25 May 2019. 